\title{
Mechanistic investigation of methane steam reforming over Ce-promoted Ni/SBA-15 catalyst
}

\author{
Viswanathan Arcotumapathy ${ }^{1} \cdot$ Feraih Sh Alenazey $^{3} \cdot$ Raja L. Al-Otaibi $^{3}$. \\ Dai-Viet N. $\mathrm{Vo}^{2} \cdot$ Faisal M. Alotaibi $^{3} \cdot$ Adesoji A. Adesina $^{4}$
}

Received: 22 April 2015 / Accepted: 29 June 2015/Published online: 11 August 2015

(C) The Author(s) 2015. This article is published with open access at Springerlink.com

\begin{abstract}
Methane steam reforming experiments were carried out at atmospheric pressure for temperatures between 873 and $1073 \mathrm{~K}$ and by varying the partial pressure of methane and steam to achieve S:C between 0.5 and 2.5. Mechanistic considerations for Methane steam reforming (MSR) were derived on the basis of Langmuir-Hinshelwood and Eley-Rideal reaction mechanisms based on single- and dual-site associative and dissociative adsorption of one or both reactants. However, discrimination of these models on statistical and thermodynamic grounds revealed that the model representing a single-site dissociative adsorption of methane and steam most adequately explained the data. However, the product formation rates from these experiments were reasonably captured by power-law model. The parameter estimates from the power-law model revealed an order of 0.94 with respect to methane and -0.16 for steam with activation energy of $49.8 \mathrm{~kJ} \mathrm{~mol}^{-1}$ for MSR. The negative order with respect to steam for methane consumption was likely due to steam inhibition.
\end{abstract}

Electronic supplementary material The online version of this article (doi:10.1007/s13203-015-0121-2) contains supplementary material, which is available to authorized users.

Adesoji A. Adesina

sojiadesina@gmail.com

1 Reactor Engineering and Technology Group, School of Chemical Engineering, University of New South Wales, Sydney, NSW 2052, Australia

2 Faculty of Chemical and Natural Resources Engineering, University Malaysia Pahang, Lebuhraya Tun Razak, 26300 Gambang, Kuantan, Pahang, Malaysia

3 King Abdulaziz City for Science and Technology, Riyadh 11442, Saudi Arabia

4 ATODATECH LLC, Brentwood, CA 94513, USA
Keywords Steam reforming $\cdot$ Methane $\cdot$ SBA-15 $\cdot$ Nickel catalyst $\cdot$ Ceria-promotion $\cdot$ Kinetic models

\section{Introduction}

Methane steam reforming (MSR) is the most important, well-established and economical route which currently accounts to $48 \%$ of the global hydrogen production $[1,2]$. Hydrogen or syngas produced via MSR (cf. reaction 1) over Ni-based catalysts is employed in the manufacturing of methanol, ammonia and the Fischer-Tropsch synthesis of hydrocarbons.

$$
\begin{aligned}
& \mathrm{CH}_{4}+\mathrm{H}_{2} \mathrm{O} \rightleftharpoons \mathrm{CO}+3 \mathrm{H}_{2} \quad \Delta H_{298}^{0}=205.8 \mathrm{~kJ} \mathrm{~mol}^{-1}, \\
& \mathrm{CO}+\mathrm{H}_{2} \mathrm{O} \rightleftharpoons \mathrm{CO}_{2}+\mathrm{H}_{2} \quad \Delta H_{298}^{0}=-41 \mathrm{~kJ} \mathrm{~mol}^{-1} .
\end{aligned}
$$

Carbon deposition via hydrocarbon dehydrogenation or $\mathrm{CO}$ dissociation (the Boudouard reaction) is a deleterious competing reaction. The performance of the catalyst is typically governed by the particular mechanism on the catalyst [3]. The identification of the sequence of elementary steps in the reaction has been the subject of many investigations and has been corroborated through the application of formal Langmuir-Hinshelwood (LH) and Eley-Rideal (ER) mechanistic formulations [4-11]. In the past decades, several investigations were carried out to explore the mechanism of the MSR and to develop kinetic models for this such complex process. One such kinetic expression to explain the MSR mechanism was proposed by $\mathrm{Xu}$ and Froment [12]. Their experiments were carried out over $\mathrm{Ni} / \mathrm{MgAl}_{2} \mathrm{O}_{4}$ spinel catalyst, and they claimed that the adsorption of $\mathrm{CO}$ and subsequent formation of $\mathrm{CO}_{2}$ on 
the active sites were the rate-determining steps (RDS). The kinetic models of MSR in the previous study, conducted by $\mathrm{Xu}$ and Froment, was implemented by Wang et al. [13] to develop the most effective kinetic models for MSR. One of the major claims of that study was the significant enhancement of operating temperatures on the carbon deposition as well as the role of the excess steam in the carbon gasification process. In another study conducted by Bradford and Vannice [14] with $\mathrm{Ni}$ supported on either $\mathrm{MgO}$ or $\mathrm{TiO}_{2}$, the surface decomposition of $\mathrm{CH}_{4}$ (to $\mathrm{CH}_{\mathrm{x}}$, $0<\mathrm{x}<4$ ) and formation $\mathrm{CH}_{\mathrm{x}} \mathrm{O}$ were found to be the ratecontrolling steps. The support also seemed to serve as a sink for surface hydroxyl species which facilitates $\mathrm{CH}_{\mathrm{x}} \mathrm{O}$ formation (reaction between adsorbed $\mathrm{CH}_{\mathrm{x}}$ and surface $\mathrm{OH})$ at the metal-support interface. They suggested that $\mathrm{CO}_{2}$ participation was via the reverse WGS reaction and proposed a kinetic model which was insensitive to the value of $x$. Significantly, the associated mechanism also appeared to be useful for the description of the steam reforming reaction over the same catalyst system.

Berman et al. [15] employed $2 \% \mathrm{Ru} / 4.8 \% \mathrm{MnO} / \alpha-$ $\mathrm{Al}_{2} \mathrm{O}_{3}$ catalyst and observed a decrease in methane consumption with an increase in S:C (steam-to-carbon) and reported that the RDS was the bonding of nascent oxygen species on the active Ru sites and gasification of adsorbed carbon by this intermediate to form adsorbed $\mathrm{CO}$ on those sites. Furthermore, an important proposition of the reaction mechanism indicates that the steam molecules were adsorbed on the support active sites and subsequently dissociate on nearby metal sites into adsorbed hydrogen and hydroxyl species, suggesting that some of the reaction intermediates were support related which was analogous to the claims made by Bradford and Vannice [14]. A similar negative influence of steam partial pressure for MSR reactions over Ni/YSZ (yttria-stabilized zirconia) were observed by Dicks et al. [16]. However, Wei and Iglesia [17] claimed that the concentration of steam was kinetically irrelevant with respect to MSR rate based on their experiments conducted over $\mathrm{Ni} / \mathrm{MgO}$ catalyst. Hence, the only rate-determining step is the methane dissociation on the metal sites $(\mathrm{C}-\mathrm{H}$ bond activation). This view was reflected by Zeppieri et al. [17] based on their investigation of MSR over $\mathrm{BaRh}_{\mathrm{x}-}$ $\mathrm{Zr}_{(1-\mathrm{x})} \mathrm{O}_{3}$ catalyst $(5 \mathrm{wt} \% \mathrm{Rh}$ ). The studies by Wei and Iglesia [17] and Zeppieri et al. [18] involved alkalis, Mg and $\mathrm{Ba}$, respectively, which purportedly enhance steam adsorption and in turn spill-over to metal sites [19]. Therefore, the elemental composition of the MSR catalyst is significant from the stand point of methane conversion [20]. In these investigations, methane reforming inhibition by carbon deposition was inevitable [21].

In view of the foregoing literature evidence, there is a need to procure a catalyst for MSR which would be highly active, ensures desired product selectivity and is reasonably stable during the course of the reaction. In a previous study [22], we employed artificial neural network (ANN) analysis of MSR data covering two decades of investigations from different research groups. The ANN input matrix included catalyst design variables, viz $\mathrm{Ni}$ loading, support type, for example, $\mathrm{SBA}-15, \mathrm{SiO}_{2}, \alpha-\mathrm{Al}_{2} \mathrm{O}_{3}$ and $\gamma-\mathrm{Al}_{2} \mathrm{O}_{3}$; promoters- $\mathrm{B}, \mathrm{Mo}, \mathrm{Zr}, \mathrm{Ce}$, catalyst reduction temperature using $\mathrm{H}_{2}$ as well as reactor operating variables such as $\mathrm{S}: \mathrm{C}$ ratio $W_{\text {cat }} / F_{\mathrm{CH}_{4}}$, reforming temperature and pressure to determine the overall product yield and conversion [21]. Results from the ANN model were taken further for empirical verification and the experimental outcomes suggested that a catalyst with composition $1 \mathrm{wt} \% \mathrm{Ce} / 10$ wt.\% Ni/SBA-15 may be most suitable for the methane reforming reaction [22]. Therefore, methane consumption rates over $1 \mathrm{wt} \% \mathrm{Ce} / 10 \mathrm{wt} \% \mathrm{Ni} / \mathrm{SBA}-15$ was used to evaluate the intrinsic kinetics for MSR employing empirical power-law modelling which elucidated approximately 1 st (0.94) order with respect to methane and a negative $(-0.16)$ order dependency on steam [22]. Further, in this study, we have used the methane consumption data from experiments carried out in our previous study [22] and evaluated in terms of the formal $\mathrm{LH}$ and ER models to determine MSR mechanism over $1 \mathrm{wt} \% \mathrm{Ce} / 10 \mathrm{wt} . \% \mathrm{Ni} /$ SBA-15. In this investigation, the mechanistic models were proposed using reaction pathways that are defined by the most abundant reactive intermediates (MARI) which are converted into products through surface reaction over the one or more catalyst active sites [6, 23-25]. Nevertheless, mechanistic model based on single-site dissociative adsorption of methane and steam adequately captured the rate behaviour on the $\mathrm{Ce} / \mathrm{Ni} / \mathrm{SBA}-15$ catalyst.

\section{Experimental}

\section{Support and catalyst preparation}

The SBA-15 support was synthesized as detailed by Zhao et al. [26], a mixture of $\mathrm{HCl}$ and tri-block copolymer $\left(\mathrm{EO}_{20}-\mathrm{PO}_{70}-\mathrm{EO}_{20}\right)$ (Pluronic $\mathrm{P} 123$ ) (chemicals used in this study were procured from Sigma-Aldrich, unless otherwise specified) was stirred continuously at $308 \mathrm{~K}$ until the copolymer was dissolved completely. Tetraethyl orthosilicate was added to the mixture, and the stirring was continued for another $20 \mathrm{~h}$, at $308 \mathrm{~K}$; later the mixture was held at $373 \mathrm{~K}$ for $48 \mathrm{~h}$. Upon filtration, the solid obtained was calcined at $773 \mathrm{~K}$ for $6 \mathrm{~h}$, to remove the template resulting in pristine white $\mathrm{SBA}-15$ which was pelletised at six ton pressure followed by size reduction and pre-treatment at $1073 \mathrm{~K}$ for $6 \mathrm{~h}$. Aqueous solutions of $\mathrm{Ni}\left(\mathrm{NO}_{3}\right)_{2-}$ $6 \mathrm{H}_{2} \mathrm{O}$ and $\mathrm{Ce}\left(\mathrm{NO}_{3}\right)_{3} \cdot 6 \mathrm{H}_{2} \mathrm{O}$ were used as precursors for $\mathrm{Ni}$ and $\mathrm{Ce}$, respectively. The catalysts 1 wt.\% Ce/10 wt.\% Ni/ 
SBA-15 was prepared via wet impregnation of SBA-15 support using $\mathrm{Ni}$ and $\mathrm{Ce}$ precursors. After impregnation, the wet solid samples were dried at $375 \mathrm{~K}$ for $24 \mathrm{~h}$ followed by calcination in air at $1123 \mathrm{~K}$ for $6 \mathrm{~h}$ to obtain the oxide catalysts.

\section{Catalysts characterization}

Multi-point BET surface area, pore volume and diameter of both fresh and used catalysts were measured via $\mathrm{N}_{2}$ physisorption at $77 \mathrm{~K}$ using Quantachrome Autosorb unit, and the samples were held at $573 \mathrm{~K}$ for $3 \mathrm{~h}$ before analysis. Powder X-ray diffraction (XRD) pattern of the calcined catalyst was obtained on X'pert Pro multipurpose X-ray diffraction (MPD) system using $\mathrm{Cu} \mathrm{K} \alpha$ radiation $(\lambda=0.154 \mathrm{~nm})$ operated at $40 \mathrm{~mA}$ and $45 \mathrm{kV}$. $\mathrm{NH}_{3^{-}}$, $\mathrm{CO}_{2}$-temperature-programmed desorption (TPD) and pulse $\mathrm{H}_{2}$-chemisorption were conducted employing Micromeritics Autochem 2910. The calcined catalysts were reduced in situ with $\mathrm{H}_{2}$ at $1073 \mathrm{~K}$ for $2 \mathrm{~h}$ at a heating rate of $10 \mathrm{~K} \mathrm{~min}^{-1}$ and then cooled to $383 \mathrm{~K}$ under flowing $\mathrm{N}_{2}$, followed by pulse injection of $10 \% \mathrm{H}_{2} / \mathrm{N}_{2}$. The solid sample was cooled to $323 \mathrm{~K}$ after reduction for $\mathrm{NH}_{3^{-}}$and $\mathrm{CO}_{2}$-TPD followed by passage of $10 \% \mathrm{NH}_{3} / \mathrm{N}_{2}$ and $10 \%$ $\mathrm{CO}_{2} / \mathrm{He}$, respectively, and subsequent desorption of the relevant probe gas at heating rates of 10, 15, 20 and $30 \mathrm{~K} \mathrm{~min}^{-1}$.

\section{Catalysts activity evaluation and reaction metrics}

The catalyst activity test was conducted in a stainless steel fixed bed reactor operated under atmospheric pressure with an internal diameter of $10 \mathrm{~mm}$ using $0.25 \mathrm{~g}$ of catalyst (with particle size 140-200 $\mu \mathrm{m}$ ) supported on quartz wool. Distilled and deionised water was fed in specific quantities from a small reservoir via Gilson Minipuls 3M 312 peristaltic pump by passage through a steam generator and mixer maintained at $453 \mathrm{~K}$ to form $\mathrm{S}: \mathrm{C}$ feed mixture with ratios varying from $0.5: 1$ to $2.5: 1$. This mixture was further diluted in Ar and supplied as feed stream (at a fixed gashourly space velocity, GHSV $=2.5 \times 10^{4} \mathrm{~h}^{-1}$ ) downwards from the top end of the reactor. These conditions ensured negligible external and internal transport intrusions in the collection of subsequent rate data. Runs were carried out in the range 873-1073 K. Prior to each activity test, the catalyst was reduced in a stream of $50 \% \mathrm{H}_{2} / \mathrm{Ar}$ flowing at $55 \mathrm{~mL} \min ^{-1}$ for $2 \mathrm{~h}$ at $1073 \mathrm{~K}$. Moisture was removed by passing the gas over a steam trap maintained at $275 \mathrm{~K}$, and the dry gas composition was analysed by gas chromatography on a Shimadzu GC-8A equipped with a thermal conductivity detector.

The catalyst performance was evaluated in terms of $\mathrm{CH}_{4}$ conversion $\left(X_{\mathrm{CH}_{4}}\right)$, consumption rate $\left(r_{\mathrm{CH}_{4}}\right)$, product selectivity $\left(\mathrm{S}_{\mathrm{i}}, \mathrm{i}=\mathrm{H}_{2}, \mathrm{CO}\right.$ and $\left.\mathrm{CO}_{2}\right)$ and product yield $\left(Y_{\mathrm{i}}\right)$ that are calculated as shown in Eqs. 3-8.

$X_{\mathrm{CH}_{4}}=\frac{F_{\mathrm{CH}_{4}}^{\mathrm{In}}-F_{\mathrm{CH}_{4}}^{\mathrm{Out}}}{F_{\mathrm{CH}_{4}}^{\mathrm{In}}}$,

$r_{\mathrm{CH}_{4}}=\frac{F_{\mathrm{CH} 4}^{\mathrm{In}}-F_{\mathrm{CH} 4}^{\mathrm{Out}}}{M_{\mathrm{SA}} \times W_{\text {catalyst }}}$,

$\mathrm{S}_{\mathrm{i}}=\frac{r_{i}}{\sum_{\mathrm{i}=\mathrm{H}_{2}, \mathrm{CO}, \mathrm{CO}_{2}} r_{i}}$,

$Y_{\mathrm{H}_{2}}=\frac{2 \mathrm{~F}_{\mathrm{H}_{2}}^{\text {out }}}{3\left(\mathrm{~F}_{\mathrm{CH}_{4}}^{\text {in }}+\mathrm{F}_{\mathrm{CH}_{2} \mathrm{O}}^{\text {in }}\right)} \times 100$,

$Y_{\mathrm{CO}}=\frac{2 F_{\mathrm{CO}_{2}}^{\text {out }}}{\left(F_{\mathrm{CH}_{4}}^{\text {in }}+F_{\mathrm{H}_{2} \mathrm{O}}^{\text {in }}\right)} \times 100$,

$Y_{\mathrm{CO}_{2}}=\frac{3 F_{\mathrm{CO}_{2}}^{\mathrm{Out}}}{\left(F_{\mathrm{CH}_{4}}^{\mathrm{in}}+F_{\mathrm{H}_{2} \mathrm{O}}^{\mathrm{in}}\right)} \times 100$,

where $\mathrm{F}$ stands for molar flow rate $\left(\mathrm{mol} \mathrm{s}^{-1}\right), \mathrm{w}_{\text {catalyst }}$ is the catalyst weight $(\mathrm{g})$ used in the reaction, $\mathrm{M}_{\mathrm{SA}}$ is the active metal surface area $\left(\mathrm{m}^{2} \mathrm{~g}_{\text {catalyst }}^{-1}\right)$ and $\mathrm{r}_{\mathrm{CH}_{4}}$ is the specific activity for methane consumption $\left(\mathrm{mol} \mathrm{m}^{-2} \mathrm{~s}^{-1}\right.$ )

\section{Results and discussion}

\section{Catalyst characterization}

The physiochemical properties of calcined support, unpromoted and promoted catalysts are presented in Table 1; BET surface area, pore volume and pore size of calcined catalysts had smaller values than the support as a result of pore blockage by $\mathrm{Ni}$ metal particles. A similar trend was observed between unpromoted and promoted SBA-15 supported catalysts.

The Ni metal dispersion and specific metal surface area for SBA-15-supported catalysts were found to be low due to the increased metal particle size resulting from a high ratio of metal deposition in the abundant mesopores to the metal deposition on surface of SBA-15 structure [27].

Figure $1 \mathrm{a}, \mathrm{b}$ shows the $\mathrm{NH}_{3}-$ and $\mathrm{CO}_{2}$-TPD profiles of $\mathrm{Ce} / \mathrm{Ni} / \mathrm{SBA}-15$ catalyst. Ce promotion resulted in decreasing the acid-to-basic sites concentration of $\mathrm{Ni} /$ SBA-15 catalyst by $12 \%$ while Ni loading of the bare support lead to significant increase of $171 \%$. The SBA-15 support has weak Lewis acid (465-690 K) and basic sites $(365-430 \mathrm{~K})$, which is in agreement with other studies [28, 29]. The activation and deactivation kinetics corresponding to the catalyst property used in this study was discussed in detail in our previous work [22] 
Table 1 Physiochemical properties of support, unpromoted and promoted catalysts

\begin{tabular}{|c|c|c|c|}
\hline Properties & SBA-15 & $\begin{array}{l}10 \text { wt. } \% \\
\text { Ni/SBA- } \\
15\end{array}$ & $\begin{array}{l}1 \text { wt. } \% \mathrm{Ce} / 10 \\
\text { wt.\% Ni/ } \\
\text { SBA-15 }\end{array}$ \\
\hline $\begin{array}{l}\text { BET } \\
\text { surface area }\left(\mathrm{m}^{2} \mathrm{~g}_{\text {catalyst }}^{-1}\right)\end{array}$ & 297.2 & 252.6 & 243.4 \\
\hline $\begin{array}{l}\text { Pore volume } \\
\left(\mathrm{cm}^{3} \mathrm{~g}_{\text {catalyst }}^{-1}\right)\end{array}$ & 0.6 & 0.51 & 0.42 \\
\hline Pore diameter $(\mathrm{nm})$ & 6.1 & 5.1 & 5.1 \\
\hline Dispersion $\%$ & N/A & 5.0 & 5.4 \\
\hline Metal Surface area $\left(\mathrm{m}^{2} \mathrm{~g}_{\text {catalyst }}^{-1}\right)$ & N/A & 3.30 & 3.40 \\
\hline $\begin{array}{l}\text { Active particle size }\left(\mathrm{d}_{\mathrm{p}}\right)(\mathrm{nm}) \\
-\Delta H_{d}, \mathrm{NH}_{3}\left(\mathrm{~kJ} \mathrm{~mol}^{-1}\right)\end{array}$ & N/A & 20.4 & 20.0 \\
\hline Peak I & 20.4 & 49.8 & 46.72 \\
\hline $\begin{array}{l}\text { Peak II } \\
-\Delta H_{d}, C O_{2}\left(\mathrm{~kJ} \mathrm{~mol}^{-1}\right)\end{array}$ & N/A & N/A & N/A \\
\hline Peak I & 33.8 & 32.2 & 33.06 \\
\hline Peak II & N/A & N/A & N/A \\
\hline $\begin{array}{l}\text { Acid site concentration } \\
\left.(\mu \mathrm{mol} \mathrm{m})^{-2}\right)\end{array}$ & & & \\
\hline Peak I & 0.17 & 0.71 & 0.8 \\
\hline Peak II & N/A & N/A & N/A \\
\hline $\begin{array}{l}\text { Basic site concentration } \\
\quad\left(\mu \mathrm{mol} \mathrm{m} \mathrm{m}^{-2}\right)\end{array}$ & & & \\
\hline Peak I & 0.07 & 0.11 & 0.14 \\
\hline Peak II & N/A & N/A & N/A \\
\hline Acid:basic sites ratio & 2.4 & 6.5 & 5.7 \\
\hline
\end{tabular}

Figure 2 shows small-angle X-ray diffractogram of synthesized SBA-15 after removal of template at $773 \mathrm{~K}$ for $6 \mathrm{~h}$; distinctive three peaks which can be indexed as $\left(\begin{array}{lll}1 & 0 & 0\end{array}\right)$ (1 110$)$ and (2 000 ) between $2 \theta$ angle of $0.9^{\circ}$ to $1.7^{\circ}$ validate the $p 6 \mathrm{~mm}$ hexagonal symmetry of the mesopores, while the same X-ray diffractogram enlarged by an order of 20 shows small but sharp peaks between $2^{\circ}$ and $3.5^{\circ}$ associated to $\left(\begin{array}{lll}2 & 1 & 0\end{array}\right)\left(\begin{array}{lll}3 & 0 & 0\end{array}\right)\left(\begin{array}{lll}2 & 2 & 0\end{array}\right)$ and $\left(\begin{array}{lll}3 & 1 & 0\end{array}\right)$ indicating the abundance of these mesopores [26].

\section{Effect of reactant partial pressure on product distribution}

It is worth mentioning that Kinetic and mechanism investigations may be carried out by employing mole fraction or partial pressure of reactants for ideal gas mixtures [3]. Methane steam reforming and products formation rates were obtained from MSR runs carried out at temperatures between 873 and $1073 \mathrm{~K}$ by varying $P_{\mathrm{CH}_{4}}$ between 9.1 and $45.6 \mathrm{kPa}$ and $P_{\mathrm{H}_{2} \mathrm{O}}$ between 11.4 and $57.0 \mathrm{kPa}$, which corresponds to $\mathrm{S}: \mathrm{C}$ of $0.5: 1-2.5: 1$ and free from any transport limitations [21]. Figure 3 shows a representative transient profiles of these feed composition for methane
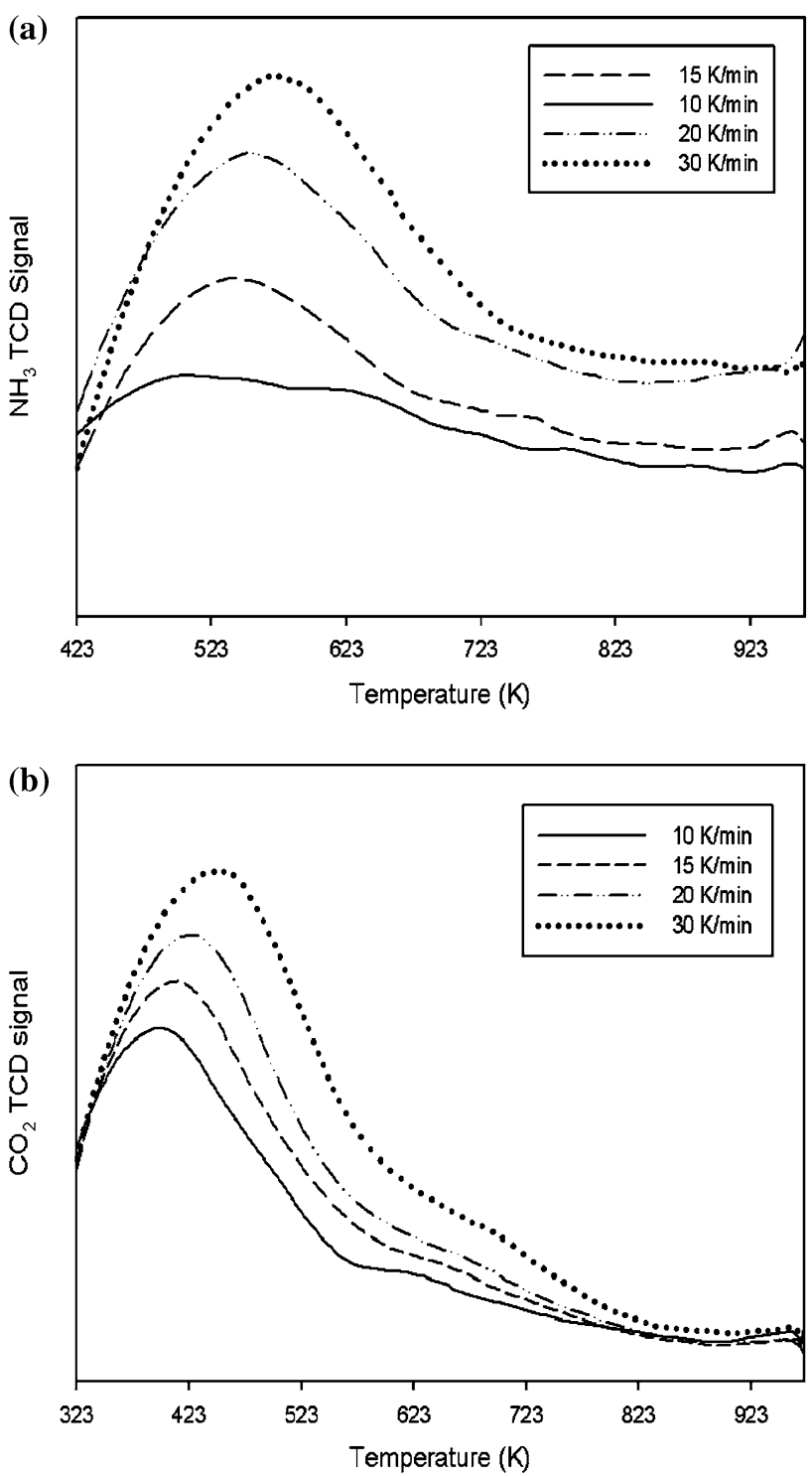

Fig. 1 TCD signals for a $\mathrm{NH}_{3}-\mathrm{TPD}$ and $\mathbf{b} \mathrm{CO}_{2}-\mathrm{TPD}$ on calcined 1 wt.\% Ce/10 wt.\% Ni/SBA- 15

partial pressure $\left(P_{\mathrm{CH}_{4}}\right) 11.41 \mathrm{kPa}$ and steam partial pressure $\left(P_{\mathrm{H}_{2} \mathrm{O}}\right) 22.82 \mathrm{kPa}$ (i.e., $\left.\mathrm{S}: \mathrm{C}=2: 1\right)$ at a temperature of $1073 \mathrm{~K}$. Figure 3 displays methane conversion levels reaching constancy very early during reforming, which indicates steady-state condition. However, $\mathrm{CO}$ initially peaked before levelling off, while $\mathrm{CO}_{2}$ showed a steady increase with time to plateau after $3 \mathrm{~h}$ time-on-stream. In similarity with the methane conversion profiles, $\mathrm{H}_{2}$ formation rates exhibited quick steady state and thereafter remained invariant with time.

Figures 4, 5 and 6 show the product selectivity, ratio and yield, respectively, as a function of $P_{\mathrm{CH}_{4}}$ and $P_{\mathrm{H}_{2} \mathrm{O}}$ at $1073 \mathrm{~K}$. Figure $4 \mathrm{a}$, b, clearly indicates that the change in partial pressure of methane or steam does not affect $\mathrm{H}_{2}$ selectivity significantly. However, $\mathrm{CO}$ selectivity 


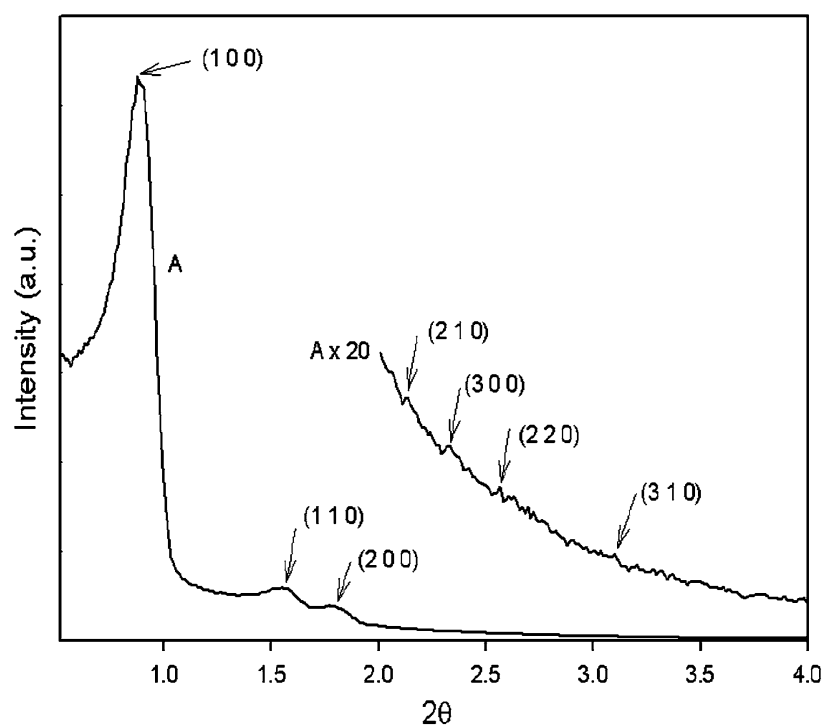

Fig. 2 Template removed small-angle XRD diffractogram of SBA15



Fig. 3 Transient dry composition profiles of methane steam reforming and $\mathrm{H}_{2}, \mathrm{CO}$ and $\mathrm{CO}_{2}$ for $\mathrm{S}: \mathrm{C}=2: 1$ at $1073 \mathrm{~K}$

decreased with increasing $P_{\mathrm{H}_{2} \mathrm{O}}$ (cf. Fig. 4b) or with decreasing (cf. Fig. 4a) and conversely a corresponding increase was observed in $\mathrm{CO}_{2}$ selectivity. Maximum $\mathrm{CO}$ selectivity (Fig. 4a, b) and yield (Fig. 6a, b) were observed only when $P_{\mathrm{CH} 4}=P_{\mathrm{H} 2 \mathrm{O}}$; this behaviour substantiates that increasing steam partial pressure results in more $\mathrm{CO}$ converted to $\mathrm{CO} 2$ via water-gas shift (WGS) reaction (cf. Eq. 2). Furthermore, this fact was reflected in product ratios (cf. Fig. 5a, b). Increasing partial pressure of steam resulted in $\mathrm{H}_{2}: \mathrm{CO}$ increase while $\mathrm{H}_{2}: \mathrm{CO}_{2}$ and $\mathrm{CO}: \mathrm{CO}_{2}$ decreased. Both $\mathrm{H}_{2}$ and $\mathrm{CO}_{2}$ were produced during WGS

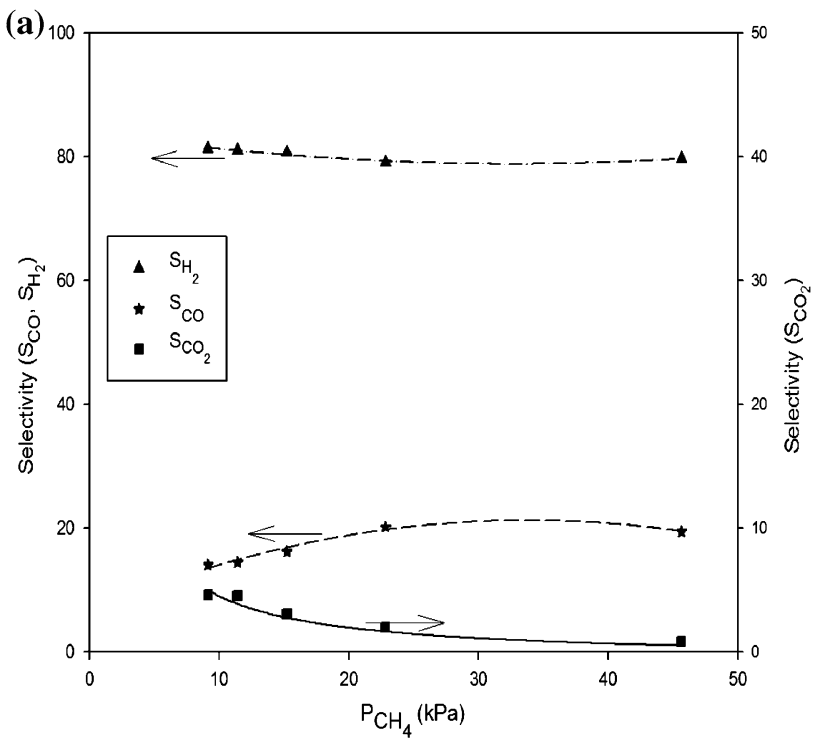

(b)

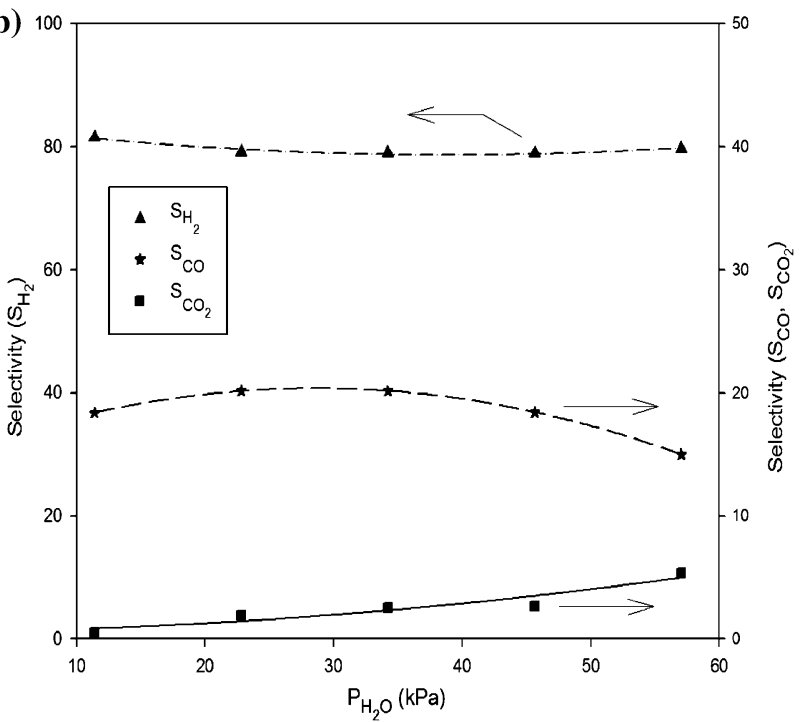

Fig. 4 a Selectivity of products at $1073 \mathrm{~K}$ as function of $P_{\mathrm{CH}_{4}}$ $\left(P_{\mathrm{H}_{2} \mathrm{O}}=22.82 \mathrm{kPa}\right)$, b selectivity of products at $1073 \mathrm{~K}$ as function of $P_{\mathrm{H}_{2} \mathrm{O}}\left(P_{\mathrm{CH}_{4}}=22.82 \mathrm{kPa}\right)$

reaction; $\mathrm{H}_{2}$ production rates were in order of magnitude higher in comparison to $\mathrm{CO}_{2}$ rates. The yield profiles (cf. Fig. $6 \mathrm{a}, \mathrm{b})$ were similar to selectivity profiles with the exception of $\mathrm{H}_{2}$ yield.

Maximum $\mathrm{H}_{2}$ yield was observed only when $P_{\mathrm{H}_{2} \mathrm{O}}=$ $P_{\mathrm{CH}_{4}}$; yield was measured on the basis of net production of $\mathrm{H}_{2}$ from total amount of $\mathrm{H}_{2} \mathrm{O}$ available in the feed composition. Although an increase in steam partial pressure contributes to a corresponding increase in $\mathrm{H}_{2}$ in the feed. This resulted in a fractional $\mathrm{H}_{2}$ increase in the products, which subsequently reflected as a significant decrease in $\mathrm{H}_{2}$ yield. These observations evidently indicate a significant quantity of $\mathrm{H}_{2}$ was produced via 

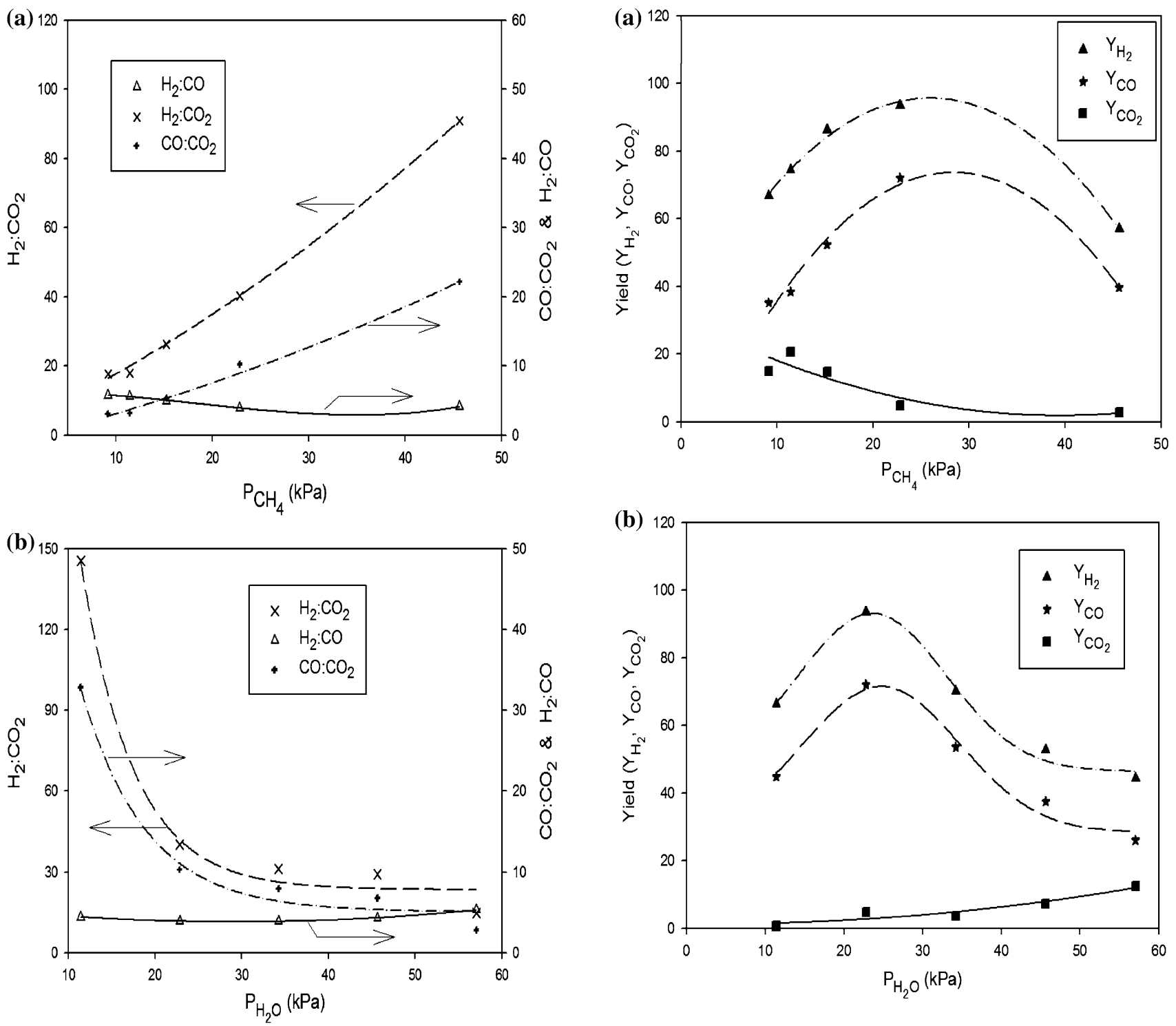

Fig. 5 a Ratio of products at $1073 \mathrm{~K}$ as function of $P_{\mathrm{CH}_{4}}$ $\left(P_{\mathrm{H}_{2} \mathrm{O}}=22.82 \mathrm{kPa}\right)$, b ratio of products at $1073 \mathrm{~K}$ as function of $P_{\mathrm{H}_{2} \mathrm{O}}\left(P_{\mathrm{CH}_{4}}=22.82 \mathrm{kPa}\right)$

reforming, and a very small fraction was produced via WGS reaction.

\section{Mechanistic considerations}

Kinetic rate expressions with Langmuir-Hinshelwood (LH) and Eley-Rideal (ER) approach were considered. Mechanistic models were proposed on the basis of singleand dual-site Langmuir-Hinshelwood mechanisms. Employing Eley-Rideal models which admit the possibility of one reactant remaining in gas phase while the other is adsorbed on the active site were explored. Both the approaches involved associative and dissociative adsorption of the reactants $[17,19,30]$.

Fig. 6 a Product yields at $1073 \mathrm{~K}$ as function of $P_{\mathrm{CH}_{4}}$ $\left(P_{\mathrm{H}_{2} \mathrm{O}}=22.82 \mathrm{kPa}\right), \mathbf{b}$ Product yields at $1073 \mathrm{~K}$ as function of $P_{\mathrm{H}_{2} \mathrm{O}}\left(P_{\mathrm{CH}_{4}}=22.82 \mathrm{kPa}\right)$

\section{Langmuir-Hinshelwood mechanisms}

These elementary reaction steps proposed here are routed on the assumption that methane and steam are associatively adsorbed on a single or an identical site (X represents active site):

$$
\begin{aligned}
& \mathrm{CH}_{4}+\mathrm{X} \leftrightarrow \mathrm{CH}_{4}-\mathrm{X} \\
& \mathrm{H}_{2} \mathrm{O}+\mathrm{X} \leftrightarrow \mathrm{H}_{2} \mathrm{O}-\mathrm{X} \\
& \mathrm{CH}_{4}-\mathrm{X}+\mathrm{H}_{2} \mathrm{O}-\mathrm{X} \rightarrow \mathrm{CHO}-\mathrm{X}+2 \mathrm{H}_{2}+\mathrm{H}-\mathrm{X} \\
& \mathrm{CHO}-\mathrm{X}+\mathrm{X} \leftrightarrow \mathrm{CO}-\mathrm{X}+\mathrm{H}-\mathrm{X} \\
& \mathrm{CO}-\mathrm{X}+\mathrm{H}_{2} \mathrm{O}-\mathrm{X} \rightarrow \mathrm{CO}_{2}-\mathrm{X}+\mathrm{H}_{2}-\mathrm{X} \\
& \mathrm{CO}-\mathrm{X} \leftrightarrow \mathrm{CO}+\mathrm{X} \\
& \mathrm{CO} \mathrm{C}_{2}-\mathrm{X} \leftrightarrow \mathrm{CO}_{2}+\mathrm{X} \\
& 2 \mathrm{H}-\mathrm{X} \leftrightarrow \mathrm{H}_{2}-\mathrm{X}+\mathrm{X} \\
& \mathrm{H}_{2}-\mathrm{X} \leftrightarrow \mathrm{H}_{2}+\mathrm{X}
\end{aligned}
$$


These elementary reaction steps proposed here are based on the assumption that dissociative adsorption of methane and steam takes place on a single or an identical site:

$$
\begin{aligned}
& \mathrm{CH}_{4}+2 \mathrm{X} \leftrightarrow \mathrm{CH}_{3}-\mathrm{X}+\mathrm{H}-\mathrm{X} \\
& \mathrm{CH}_{3}-\mathrm{X}+\mathrm{X} \leftrightarrow \mathrm{CH}_{2}-\mathrm{X}+\mathrm{H}-\mathrm{X} \\
& \mathrm{CH}_{2}-\mathrm{X}+\mathrm{X} \leftrightarrow \mathrm{CH}-\mathrm{X}+\mathrm{H}-\mathrm{X} \\
& \mathrm{H}_{2} \mathrm{O}+2 \mathrm{X} \leftrightarrow \mathrm{OH}-\mathrm{X}+\mathrm{H}-\mathrm{X} \\
& \mathrm{OH}-\mathrm{X}+\mathrm{X} \leftrightarrow \mathrm{O}-\mathrm{X}+\mathrm{H}-\mathrm{X} \\
& \mathrm{CH}-\mathrm{X}+\mathrm{O}-\mathrm{X} \leftrightarrow \mathrm{CHO}-\mathrm{X}+\mathrm{H}-\mathrm{X} \\
& \mathrm{CHO}-\mathrm{X}+\mathrm{X} \leftrightarrow \mathrm{CO}-\mathrm{X}+\mathrm{H}-\mathrm{X} \\
& \mathrm{CHO}-\mathrm{X}+\mathrm{O}-\mathrm{X} \leftrightarrow \mathrm{CO}_{2}-\mathrm{X}+\mathrm{H}-\mathrm{X} \\
& \mathrm{CO}-\mathrm{X} \leftrightarrow \mathrm{CO}+\mathrm{X} \\
& \mathrm{CO}-\mathrm{X} \leftrightarrow \mathrm{CO}+\mathrm{X} \\
& 2 \mathrm{H}-\mathrm{X} \leftrightarrow \mathrm{H}_{2}-\mathrm{X}+\mathrm{X} \\
& \mathrm{H}_{2}-\mathrm{X} \leftrightarrow \mathrm{H}_{2}+\mathrm{X}
\end{aligned}
$$

The elementary reaction steps proposed below are based on the assumption that preferential associative adsorption of methane and steam on dual or different active sites $\left(\mathrm{X}_{1}\right.$ and $\mathrm{X}_{2}$ ) available on the catalyst surface:

\begin{tabular}{|c|c|c|}
\hline Model no & Model & Remarks \\
\hline 1 & $\frac{k_{r x n} P_{\mathrm{CH}_{4}} P_{\mathrm{H}_{2} \mathrm{O}}}{\left(1+K_{\mathrm{CH}_{4}} P_{\mathrm{CH}_{4}}+K_{\mathrm{H}_{2} \mathrm{O}} P_{\mathrm{H}_{2} \mathrm{O}}\right)^{2}}$ & LH model for single-site associative adsorption of both methane and steam \\
\hline 2 & $\frac{k_{r x n} P_{C_{4}} P_{H_{2} O}}{\left(1+K_{C_{4}} P_{C_{4}}\right)\left(1+K_{H_{2} O} P_{H_{2} O}\right)}$ & LH model for dual-site associative adsorption of both methane and steam \\
\hline 3 & $\frac{k_{r x n} P_{\mathrm{CH}_{4}} \sqrt{P_{\mathrm{H}_{2} \mathrm{O}}}}{\left(1+K_{\mathrm{CH}_{4}} P_{\mathrm{CH}_{4}}+\sqrt{K_{\mathrm{H}_{2} \mathrm{O}} P_{\mathrm{H}_{2} \mathrm{O}}}\right)^{2}}$ & LH model for single-site associative adsorption of methane and dissociative adsorption of steam \\
\hline 4 & $\frac{k_{r x n} P_{\mathrm{CH}_{4}} \sqrt{P_{\mathrm{H}_{2} \mathrm{O}}}}{\left(1+K_{\mathrm{CH}_{4}} P_{\mathrm{CH}_{4}}\right)+\left(1+\sqrt{K_{\mathrm{H}_{2} \mathrm{O}} P_{\mathrm{H}_{2} \mathrm{O}}}\right)}$ & LH model for dual-site associative adsorption of methane and dissociative adsorption of steam \\
\hline 5 & $\frac{k_{r x n} P_{\mathrm{H}_{2} \mathrm{O}} \sqrt{P_{\mathrm{CH}_{4}}}}{\left(1+K_{\mathrm{H}_{2} \mathrm{O}} P_{\mathrm{H}_{2}} \mathrm{O}+\sqrt{K_{\mathrm{CH}_{4}} P_{\mathrm{CH}_{4}}}\right)^{2}}$ & LH model for single-site associative adsorption of steam and dissociative adsorption of methane \\
\hline 6 & $\frac{k_{r x n} P_{\mathrm{H}_{2} \mathrm{O}} \sqrt{P_{\mathrm{CH}_{4}}}}{\left(1+\sqrt{K_{\mathrm{CH}_{4}} P_{\mathrm{CH}_{4}}}\right)\left(1+K_{\mathrm{H}_{2} \mathrm{O}} P_{\mathrm{H}_{2} \mathrm{O}}\right)}$ & LH model for dual-site associative adsorption of steam and dissociative adsorption of methane \\
\hline 7 & $\frac{k_{r x n} \sqrt{P_{\mathrm{H}_{2} \mathrm{O}} P_{\mathrm{CH}_{4}}}}{\left(1+\sqrt{K_{\mathrm{CH}_{4}} P_{\mathrm{CH}_{4}}}\right)+\left(1+K_{\mathrm{H}_{2} \mathrm{O}} P_{\mathrm{H}_{2} \mathrm{O}}\right)^{2}}$ & LH model for single-site dissociative adsorption of both methane and steam \\
\hline 8 & $\frac{k_{r x n} \sqrt{P_{\mathrm{CH}_{4} P_{\mathrm{CH}_{4}}}}}{\left(1+\sqrt{\left.K_{\mathrm{CH}_{4}} P_{\mathrm{CH}_{4}}\right)\left(1+\sqrt{K_{\mathrm{H}_{2} \mathrm{O}} P_{\mathrm{H}_{2} \mathrm{O}}}\right)}\right.}$ & LH model for dual-site dissociative adsorption of both methane and steam \\
\hline 9 & $\frac{k_{r x n} P_{\mathrm{CH}_{4}} P_{\mathrm{H}_{2} \mathrm{O}}}{\left(1+\sqrt{K_{\mathrm{CH}_{4}} P_{\mathrm{CH}_{4}}}\right)}$ & ER model for associative adsorption of methane with steam in gas phase \\
\hline 10 & $\frac{k_{r x n} P_{H_{2} o} o \sqrt{P_{C H_{4}}}}{\left(1+\sqrt{K_{C H_{4}} P_{C H_{4}}}\right)}$ & ER model for dissociative adsorption of methane with steam in gas phase \\
\hline 11 & $\frac{k_{r x n} P_{\mathrm{CH}_{4}} P_{\mathrm{H}_{2} \mathrm{O}}}{\left(1+K_{\mathrm{H}_{2} \mathrm{O}} P_{\mathrm{H}_{2} \mathrm{O}}\right)}$ & ER model for associative adsorption of steam with methane in gas phase \\
\hline 12 & $\frac{k_{r x n} P_{\mathrm{CH}_{4}} \sqrt{P_{\mathrm{H}_{2} \mathrm{O}}}}{\left(1+\sqrt{K_{\mathrm{H}_{2} \mathrm{O}} P_{\mathrm{H}_{2} \mathrm{O}}}\right)}$ & ER model for dissociative adsorption of steam with methane in gas phase \\
\hline
\end{tabular}

$$
\begin{aligned}
& \mathrm{CH}_{4}+\mathrm{X}_{1} \leftrightarrow \mathrm{CH}_{4}-\mathrm{X}_{1} \\
& \mathrm{H}_{2} \mathrm{O}+\mathrm{X}_{2} \leftrightarrow \mathrm{H}_{2} \mathrm{O}-\mathrm{X}_{2} \\
& \mathrm{CH}_{4}-\mathrm{X}_{1}+\mathrm{H}_{2} \mathrm{O}-\mathrm{X}_{2} \rightarrow \mathrm{CHO}-\mathrm{X}_{1}+2 \mathrm{H}_{2}+\mathrm{H}-\mathrm{X} \\
& \mathrm{CHO}-\mathrm{X}_{1}+\mathrm{X}_{2} \leftrightarrow \mathrm{CO}-\mathrm{X}_{1}+\mathrm{H}-\mathrm{X}_{22} \\
& \mathrm{CO}-\mathrm{X}_{1}+\mathrm{H}_{2} \mathrm{O}-\mathrm{X}_{2} \rightarrow \mathrm{CO}_{2}-\mathrm{X}_{1}+\mathrm{H}_{2}-\mathrm{X}_{2} \\
& \mathrm{CO}-\mathrm{X}_{1} \leftrightarrow \mathrm{CO}+\mathrm{X}_{1} \\
& \mathrm{CO}-\mathrm{X}_{1} \leftrightarrow \mathrm{CO}_{2}+\mathrm{X}_{1} \\
& 2 \mathrm{H}-\mathrm{X}_{2} \leftrightarrow \mathrm{H}_{2}-\mathrm{X}_{2}+\mathrm{X}_{2} \\
& \mathrm{H}_{2}-\mathrm{X}_{2} \leftrightarrow \mathrm{H}_{2}+\mathrm{X}_{2}
\end{aligned}
$$

The elementary reaction steps proposed below are based on the assumption that preferential dissociative adsorption of methane and steam on dual or different active sites $\left(X_{1}\right.$ and $X_{2}$ ) available on the catalyst surface:

$$
\begin{aligned}
& \mathrm{CH}_{4}+2 \mathrm{X}_{1} \leftrightarrow \mathrm{CH}_{3}-\mathrm{X}_{1}+\mathrm{H}-\mathrm{X}_{1} \\
& \mathrm{CH}_{3}-\mathrm{X}_{1}+\mathrm{X}_{1} \leftrightarrow \mathrm{CH}_{2}-\mathrm{X}_{1}+\mathrm{H}-\mathrm{X}_{1} \\
& \mathrm{H}_{2} \mathrm{O}+2 \mathrm{X}_{2} \leftrightarrow \mathrm{OH}-\mathrm{X}_{2}+\mathrm{H}-\mathrm{X}_{2} \\
& \mathrm{OH}-\mathrm{X}_{2}+\mathrm{X}_{1} \leftrightarrow \mathrm{O}-\mathrm{X}_{1}+\mathrm{H}-\mathrm{X}_{2} \\
& \mathrm{CH}_{2}-\mathrm{X}_{1}+\mathrm{O}-\mathrm{X}_{1} \leftrightarrow \mathrm{CHO}-\mathrm{X}_{1}+\mathrm{H}-\mathrm{X}_{1} \\
& \mathrm{CHO}-\mathrm{X}_{1}+\mathrm{X}_{1} \leftrightarrow \mathrm{CO}-\mathrm{X}_{1}+\mathrm{H}-\mathrm{X}_{1} \\
& \mathrm{CHO}-\mathrm{X}_{1}+\mathrm{O}-\mathrm{X}_{1} \leftrightarrow \mathrm{CO}_{2}-\mathrm{X}_{1}+\mathrm{H}-\mathrm{X}_{1} \\
& \mathrm{CO}-\mathrm{X}_{1} \leftrightarrow \mathrm{CO}+\mathrm{X}_{1} \\
& \mathrm{CO}-\mathrm{X}_{1} \leftrightarrow \mathrm{CO}_{2}+\mathrm{X}_{1} \\
& 2 \mathrm{H}-\mathrm{X}_{1} \leftrightarrow \mathrm{H}_{2}-\mathrm{X}_{1}+\mathrm{X}_{1} \\
& 2 \mathrm{H}-\mathrm{X}_{2} \leftrightarrow \mathrm{H}_{2}-\mathrm{X}_{2}+\mathrm{X}_{2} \\
& \mathrm{H}_{2}-\mathrm{X}_{1} \leftrightarrow \mathrm{H}_{2}+\mathrm{X}_{1} \\
& \mathrm{H}_{2}-\mathrm{X}_{2} \leftrightarrow \mathrm{H}_{2}+\mathrm{X}_{2} .
\end{aligned}
$$

\section{Eley-Rideal mechanism}

Associative molecular adsorption of methane with steam in the gas phase was assumed for these elementary reaction steps:

Table 2 Langmuir-Hinshelwood (LH) and Eley-Rideal (ER) rate models 
$\mathrm{CH}_{4}+\mathrm{X} \leftrightarrow \mathrm{CH}_{4}-\mathrm{X}_{1}$

$\mathrm{CH}_{4}-\mathrm{X}+\mathrm{X} \leftrightarrow \mathrm{CH}_{2}-\mathrm{X}+\mathrm{H}_{2}-\mathrm{X}$

$\mathrm{CH}_{2}-\mathrm{X}+\mathrm{H}_{2} \mathrm{O} \rightarrow \mathrm{CH}_{2} \mathrm{O}-\mathrm{X}+\mathrm{H}_{2}$

$\mathrm{CH}_{2} \mathrm{O}-\mathrm{X}+\mathrm{X} \leftrightarrow \mathrm{CHO}-\mathrm{X}+\mathrm{H}-\mathrm{X}$

$\mathrm{CHO}-\mathrm{X}+\mathrm{X} \leftrightarrow \mathrm{CO}-\mathrm{X}+\mathrm{H}-\mathrm{X}$

$\mathrm{CO}-\mathrm{X}+\mathrm{H}_{2} \mathrm{O} \rightarrow \mathrm{CO}_{2}-\mathrm{X}+\mathrm{H}_{2}$

$\mathrm{CO}_{2}-\mathrm{X} \leftrightarrow \mathrm{CO}_{2}+\mathrm{X}$

$\mathrm{CO}-\mathrm{X} \leftrightarrow \mathrm{CO}+\mathrm{X}$

$2 \mathrm{H}-\mathrm{X} \leftrightarrow \mathrm{H}_{2}-\mathrm{X}+\mathrm{X}$

$\mathrm{H}_{2}-\mathrm{X} \leftrightarrow \mathrm{H}_{2}+\mathrm{X}$

Dissociative molecular adsorption of methane with steam in the gas phase was assumed for these elementary reaction steps.

$\mathrm{CH}_{4}+2 \mathrm{X} \leftrightarrow \mathrm{CH}_{2}-\mathrm{X}+\mathrm{H}_{2}-\mathrm{X}$

$\mathrm{CH}_{2}-\mathrm{X}+\mathrm{H}_{2} \mathrm{O} \rightarrow \mathrm{CH}_{2} \mathrm{O}-\mathrm{X}+\mathrm{H}_{2}$

$\mathrm{CH}_{2} \mathrm{O}-\mathrm{X}+\mathrm{X} \rightarrow \mathrm{CHO}-\mathrm{X}+\mathrm{H}-\mathrm{X}$

$\mathrm{CHO}-\mathrm{X}+\mathrm{X} \rightarrow \mathrm{CO}-\mathrm{X}+\mathrm{H}-\mathrm{X}$

$\mathrm{CO}-\mathrm{X}+\mathrm{H}_{2} \mathrm{O} \rightarrow \mathrm{CO}_{2}-\mathrm{X}+\mathrm{H}_{2}$

$\mathrm{CO}_{2}-\mathrm{X} \leftrightarrow \mathrm{CO}_{2}+\mathrm{X}$

$\mathrm{CO}-\mathrm{X} \leftrightarrow \mathrm{CO}+\mathrm{X}$

$2 \mathrm{H}-\mathrm{X} \leftrightarrow \mathrm{H}_{2}-\mathrm{X}+\mathrm{X}$

$\mathrm{H}_{2}-\mathrm{X} \leftrightarrow \mathrm{H}_{2}+\mathrm{X}$.

By applying quasi-steady-state approximation and integrating the concept of most abundant reactive intermediate (MARI) [6, 23-25], a range of rate expressions were derived for those mechanisms laid out earlier which are summarized in Table 2 (where $P_{\mathrm{CH}_{4}}$ partial pressure of methane, $P_{\mathrm{H}_{2} \mathrm{O}}$ partial pressure of steam, $K_{\mathrm{CH}_{4}}$ : methane adsorption constant, $K_{\mathrm{H}_{2} \mathrm{O}}$ : steam adsorption constant,: $k_{\mathrm{rxn}}$ methane steam reforming constant). Illustrations of rate expression derivations are shown in Appendix A.

Further, a nonlinear regression was carried out (using POLMATH 6.0 with Levenberg-Marquardt algorithm for approximating the objective function) with the models from Table 2 using methane steam reforming data (cf. Fig. 7a, b) [22] to evaluate the estimates, $K_{\mathrm{CH}_{4}} K_{\mathrm{H}_{2} \mathrm{O}}$ and $k_{\mathrm{rxn}}$. The results from this exercise are provided in Table 3. Two criteria were used for model selection. The models were considered for further analysis if $R^{2}>0.9$ for any model across the temperature range and an apparent trend for all the estimates with respect to temperature. From Table 3, it is evident that only models 3 and 7 pass these constraints and are therefore subjected to further scrutiny.
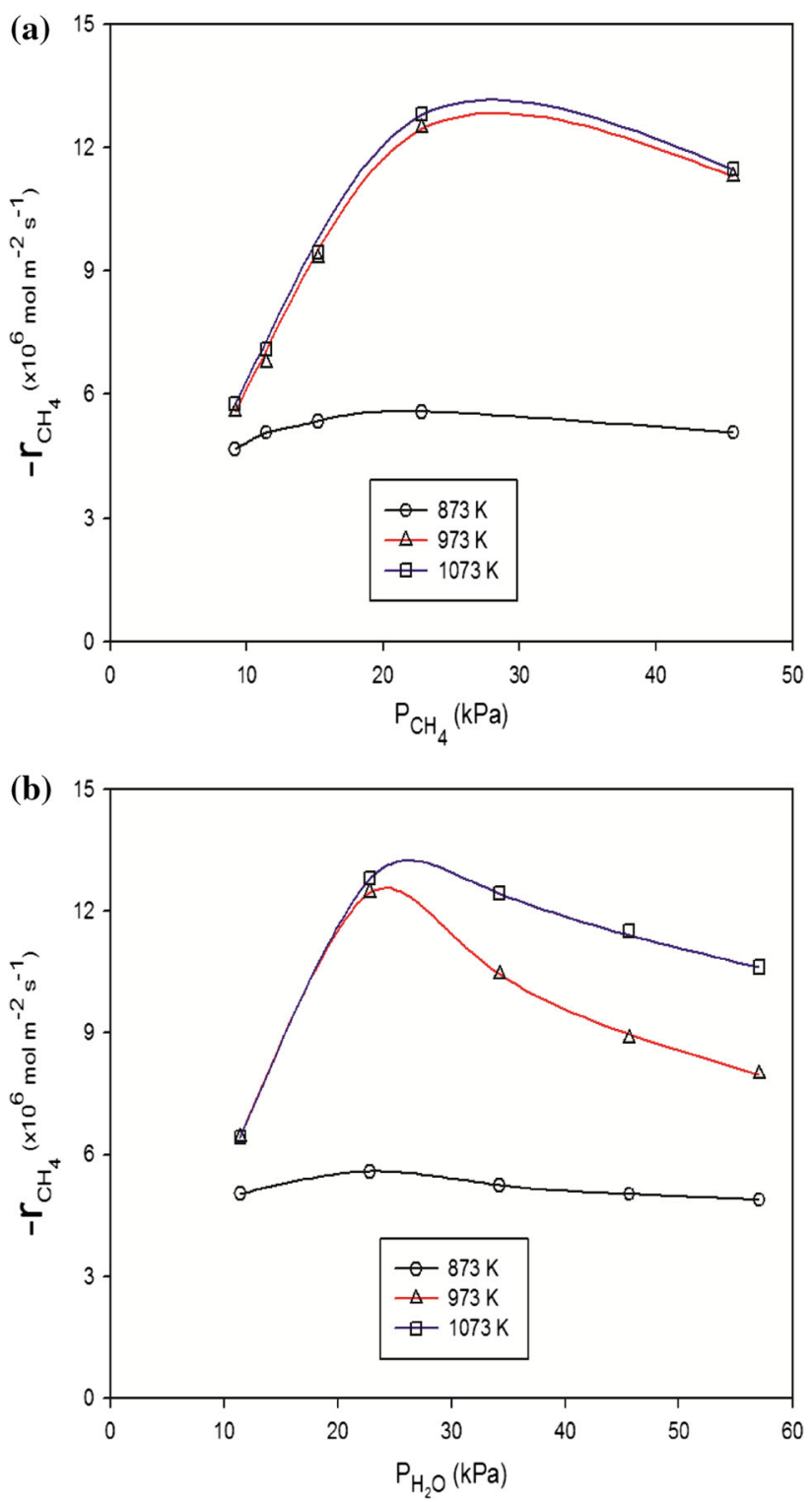

Fig. 7 a Specific $\mathrm{CH}_{4}$ consumption rates as function of $P_{\mathrm{CH}_{4}}$ $\left(P_{\mathrm{H}_{2} \mathrm{O}}=22.82 \mathrm{kPa}\right)$, b Specific $\mathrm{CH}_{4}$ consumption rates as function of $P_{\mathrm{H}_{2} \mathrm{O}}\left(P_{\mathrm{CH}_{4}}=22.82 \mathrm{kPa}\right)$

Even though these models are statistically significant, they should also have some thermodynamic relevance. Langmuir-Hinshelwood models can be assessed from the stand point of thermodynamic significance with the aid of Eq. 9 [31]:

$10 \leq-\Delta S \leq 12.2-0.0014 \Delta H$,

where $\Delta S=$ change in entropy $\left(\mathrm{J} \mathrm{mol}^{-1} \mathrm{~K}^{-1}\right)$ and

$\Delta H=$ change in enthalpy $\left(\mathrm{J} \mathrm{mol}^{-1}\right)$.

Models 3 and 7 represent Langmuir-Hinshelwood rate expressions; therefore, the criterion depicted by Eq. 9 can be employed to evaluate the thermodynamic implication. 
Table 3 Estimates of mechanistic models for methane steam reforming data

\begin{tabular}{|c|c|c|c|c|c|}
\hline Model no. & Temperature (K) & $\begin{array}{l}k_{r x n} \\
\left(10^{-7} \mathrm{~mol} \mathrm{~s}^{-1} \mathrm{~m}^{-2} \mathrm{kPa}^{-(\alpha+\beta)}\right)\end{array}$ & $\begin{array}{l}K_{\mathrm{CH}_{4}} \\
\left(\times 10^{-2} \mathrm{kPa}^{-\alpha}\right)\end{array}$ & $\begin{array}{l}K_{\mathrm{H}_{2} \mathrm{O}} \\
\left(\times 10^{-2} \mathrm{kPa}^{-\beta}\right)\end{array}$ & $R^{2}$ \\
\hline \multirow[t]{3}{*}{1} & 1073 & $2.59 \pm 0.003$ & $1.15 \pm 0.007$ & $5.01 \pm 0.002$ & 0.99 \\
\hline & 973 & $1.43 \pm 0.007$ & $1.01 \pm 0.002$ & $9.06 \pm 0.001$ & 0.99 \\
\hline & 873 & $0.92 \pm 0.007$ & $3.45 \pm 0.009$ & $4.89 \pm 0.009$ & 0.99 \\
\hline \multirow[t]{3}{*}{2} & 1073 & $16.31 \pm 0.12$ & $1.99 \pm 0.001$ & $101.01 \pm 6.18$ & 0.98 \\
\hline & 973 & $8.11 \pm 0.043$ & $3.12 \pm 0.003$ & $200.99 \pm 6.67$ & 0.93 \\
\hline & 873 & $2.12 \pm 0.009$ & $6.05 \pm 0.002$ & $32.03 \pm 0.836$ & 0.99 \\
\hline \multirow[t]{3}{*}{3} & 1073 & $39.62 \pm 0.823$ & $0.60 \pm 0.002$ & $1.26 \pm 0.009$ & 0.99 \\
\hline & 973 & $13.89 \pm 0.398$ & $1.53 \pm 0.006$ & $18.80 \pm 0.556$ & 0.93 \\
\hline & 873 & $2.32 \pm 0.008$ & $2.50 \pm 0.003$ & $101.01 \pm 8.32$ & 0.99 \\
\hline \multirow[t]{3}{*}{4} & 1073 & $12.49 \pm 0.64$ & $2.10 \pm 0.001$ & $100.10 \pm 5.98$ & 0.98 \\
\hline & 973 & $9.31 \pm 0.079$ & $2.91 \pm 0.008$ & $201.00 \pm 9.32$ & 0.92 \\
\hline & 873 & $4.13 \pm 0.002$ & $6.05 \pm 0.007$ & $25.06 \pm 0.596$ & 0.99 \\
\hline \multirow[t]{3}{*}{5} & 1073 & $4.21 \pm 0.005$ & $0.64 \pm 0.006$ & $4.08 \pm 0.008$ & 0.97 \\
\hline & 973 & $1.08 \pm 0.005$ & $0.51 \pm 0.003$ & $0.91 \pm 0.002$ & 0.70 \\
\hline & 873 & $12.09 \pm 0.047$ & $0.82 \pm 0.006$ & $0.19 \pm 0.001$ & 0.99 \\
\hline \multirow[t]{3}{*}{6} & 1073 & $1.88 \pm 0.007$ & $3.93 \pm 0.009$ & $3.93 \pm 0.004$ & 0.92 \\
\hline & 973 & $0.72 \pm 0.006$ & $3.48 \pm 0.007$ & $0.77 \pm 0.003$ & 0.49 \\
\hline & 873 & $4.43 \pm 0.002$ & $0.20 \pm 0.001$ & $27.77 \pm 0.812$ & 0.99 \\
\hline \multirow[t]{3}{*}{7} & 1073 & $154.90 \pm 0.653$ & $5.33 \pm 0.003$ & $1.40 \pm 0.002$ & 0.97 \\
\hline & 973 & $93.07 \pm 0.372$ & $16.23 \pm 0.087$ & $10.45 \pm 0.099$ & 0.96 \\
\hline & 873 & $42.27 \pm 0.028$ & $26.25 \pm 0.095$ & $89.35 \pm 2.214$ & 0.99 \\
\hline \multirow[t]{3}{*}{8} & 1073 & $10.68 \pm 0.06$ & $0.35 \pm 0.008$ & $6.52 \pm 0.009$ & 0.95 \\
\hline & 973 & $46.50 \pm 0.289$ & $3.82 \pm 0.003$ & $381.90 \pm 23.8$ & 0.92 \\
\hline & 873 & $20.98 \pm 0.31$ & $0.26 \pm 0.006$ & $101.01 \pm 14.3$ & 0.88 \\
\hline \multirow[t]{3}{*}{9} & 1073 & $6.08 \pm 0.978$ & $201.00 \pm 15.22$ & - & 0.56 \\
\hline & 973 & $2.65 \pm 0.062$ & $100.10 \pm 8.925$ & - & 0.37 \\
\hline & 873 & $0.25 \pm 0.009$ & $6.05 \pm 0.007$ & - & 0.99 \\
\hline \multirow[t]{3}{*}{10} & 1073 & $3.75 \pm 0.002$ & $110.10 \pm 6.563$ & - & 0.56 \\
\hline & 973 & $4.69 \pm 0.008$ & $201.00 \pm 8.22$ & - & 0.32 \\
\hline & 873 & $0.60 \pm 0.002$ & $0.20 \pm 0.005$ & - & 0.99 \\
\hline \multirow[t]{3}{*}{11} & 1073 & $11.18 \pm 0.01$ & - & $201.00 \pm 4.75$ & 0.98 \\
\hline & 973 & $53.62 \pm 0.9$ & - & $1109.9 \pm 127$ & 0.92 \\
\hline & 873 & $1.26 \pm 0.001$ & - & $61.81 \pm 1.042$ & 0.81 \\
\hline \multirow[t]{3}{*}{12} & 1073 & $6.70 \pm 0.009$ & - & $110.10 \pm 7.75$ & 0.97 \\
\hline & 973 & $8.68 \pm 0.007$ & - & $201.00 \pm 18.6$ & 0.84 \\
\hline & 873 & $2.04 \pm 0.004$ & - & $73.92 \pm 8.316$ & 0.81 \\
\hline
\end{tabular}

However, the change in entropies and enthalpies can be abstracted by Eq. 10:

$K=-\frac{\Delta H}{R T}+\frac{\Delta S}{R}$,

where $K=$ adsorption constant (for methane or steam),

$R=$ ideal gas constant and

$T=$ temperature $(\mathrm{K})$.

The estimated thermodynamic parameters, $\Delta H$ and $\Delta S$, for methane and steam are listed in Table 4. Apparently, model 3 failed to satisfy the thermodynamic criterion, while model 7 provides a meaningful explanation of the data. In particular, the activation energy of $50.76 \mathrm{~kJ} \mathrm{~mol}^{-1}$ for model 7 from Table 5 which is in close vicinity to the value obtained from macroscopic power-law $\left(E_{\mathrm{A}}=49.8 \mathrm{~kJ} \mathrm{~mol}^{-1}\right)$ analysis [22]. The order on methane and steam obtained through power-law model were 0.94 and -0.16 , respectively, where the negative order on steam clearly indicates that steam competes for the active sites which are the precursor for methane decomposition [22], 
Table 4 Verification of models using change in entropies and enthalpies for methane and steam

\begin{tabular}{lllll}
\hline Model no. & $\Delta \mathrm{H}$ & \multicolumn{1}{l}{$\Delta \mathrm{S}$} & $R^{2}$ & Guideline (Eqn. 9) \\
\hline Methane & & & & \\
3 & -55.11 & -93.04 & 0.94 & $10 \leq 93.04 \leq 89.36$ (No) \\
7 & -61.02 & -80.03 & 0.96 & $10 \leq 80.03 \leq 97.62$ (Yes) \\
Steam & & & & \\
3 & -168.73 & -191.37 & 0.96 & $10 \leq 191.37 \leq 248.42$ \\
& & & & $\begin{array}{l}\text { (Yes) } \\
10 \leq 185.49 \leq 238.20 \\
7\end{array}$ \\
& -161.43 & -185.49 & 0.99 & \\
& & & & (Yes) \\
\hline
\end{tabular}

Table 5 Arrhenius parameters for models 3 and 7

\begin{tabular}{llll}
\hline$-\ln k_{r x n}$ & $1 / \mathrm{T}\left(\mathrm{K}^{-1}\right)$ & $E_{\mathrm{A}}\left(\mathrm{kJ} \mathrm{mol}^{-1}\right)$ & $R^{2}$ \\
\hline Model no: 3 & & & \\
-12.4388 & 0.000932 & 111.15 & 0.99 \\
-13.4869 & 0.001028 & & \\
-15.2778 & 0.001145 & & \\
Model no: 7 & & & 0.99 \\
-11.0753 & 0.000932 & 50.76 & \\
-11.5847 & 0.001028 & & \\
-12.374 & 0.001145 & &
\end{tabular}

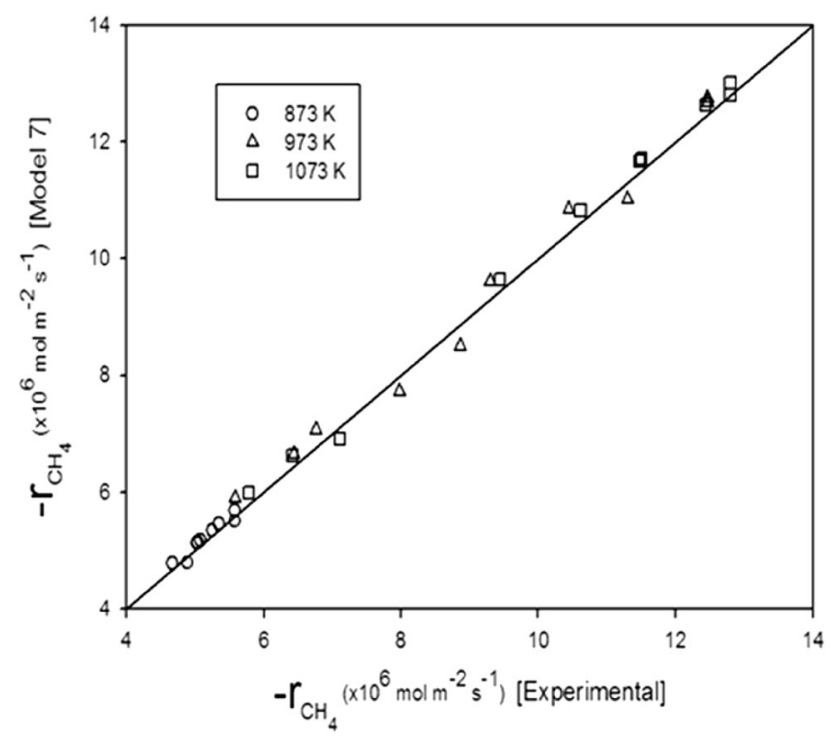

Fig. 8 Comparison between model 7 (best model) data and the experimental data

and Model 7 representing a single-site was consistent with this finding (Fig. 8).

Moreover, X-ray diffractogram of used catalysts from MSR runs carried out at 873 and $973 \mathrm{~K}$ (Fig. 9) shows small but distinct peaks at $2 \theta=37.2^{\circ}, 43.2^{\circ}$ and $62.8^{\circ}$

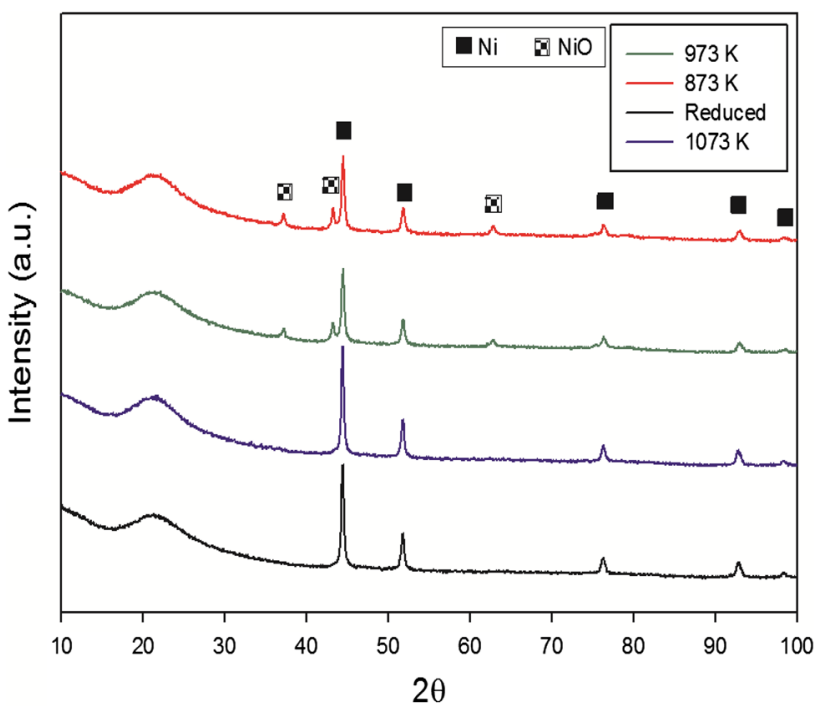

Fig. 9 X-ray diffractogram of spent $(\mathrm{S}: \mathrm{C}=2)$ at $873-1073 \mathrm{~K}$ and reduced catalysts

relative to $\mathrm{NiO}$. While diffractogram corresponding to a catalyst from reaction conducted at $1073 \mathrm{~K}$ does not show any peaks for $\mathrm{NiO}$, it is identical to the reduced catalyst pattern. Moreover, this phenomenon indicates the possible involvement of support active sites responsible for the formation of some reaction intermediate species through the adsorption followed by the dissociation of steam molecules on nearby metal active sites which was analogues to claims reported in the literature [13, 14]. Laosiripojana et al. found steam inhibition for MSR initiating around $\mathrm{S}: \mathrm{C}=1.5-2$ with an order on steam partial pressure of -0.4 [32]. Various other studies also claimed a negative order on steam for MSR [15, 16, 33-36]. Therefore, methane steam reforming over Ce-promoted Ni/SBA15 catalyst appears to proceed via a single-site dissociative adsorption of methane and steam mechanism which is reported by other researchers [12, 32, 37].

\section{Conclusions}

The kinetic analysis of reaction rate data for methane steam reforming over Ce-promoted Ni/SBA catalyst has been carried out. The Langmuir-Hinshelwood model involving single-site and dissociative adsorption of both methane and steam was adequate in explaining the variability in the experimental data while satisfying statistical significance and thermodynamic constraints. Furthermore, the model was consistent with the evidence of negative order with respect to steam for methane consumption from our previous work. The methane consumption rates tend to drop with increase in $\mathrm{S}: \mathrm{C}(\mathrm{S}: \mathrm{C}>1)$. Hence, for the catalyst used in this study, optimum methane conversion and minimum 
$\mathrm{CO}_{2}$ formation could be achieved during MSR when the $\mathrm{S}: \mathrm{C}=1$. The presence of $\mathrm{NiO}$ peaks observed in the diffractograms from spent catalyst XRD is consistent with the dissociation of steam molecule during the reaction. Therefore, MSR over 1 wt.\% Ce/10 wt.\% Ni/SBA-15 catalyst is effectively captured by a Langmuir-Hinshelwood model representing a single-site dissociative adsorption of methane and steam.

Acknowledgments Financial support of the Australian Research Council is gratefully acknowledged.

Open Access This article is distributed under the terms of the Creative Commons Attribution 4.0 International License (http:// creativecommons.org/licenses/by/4.0/), which permits unrestricted use, distribution, and reproduction in any medium, provided you give appropriate credit to the original author(s) and the source, provide a link to the Creative Commons license, and indicate if changes were made.

\section{Appendix A}

1. Langmuir-Hinshelwood model for single-site dissociative adsorption of both $\mathrm{CH}_{4}$ and $\mathrm{H}_{2} \mathrm{O}$ molecules. For dissociative adsorption of methane and steam on single site:,

$\theta \mathrm{CH}_{2} \theta \mathrm{H}_{2}=K_{\mathrm{CH}_{4}} P_{\mathrm{CH}_{4}} \theta_{X}^{2}$,

$\theta_{\mathrm{OH}} \theta_{\mathrm{H}}=K_{\mathrm{H}_{2} \mathrm{O}} P_{\mathrm{H}_{2} \mathrm{O}} \theta_{X}^{2}$,

where $\theta_{\mathrm{i}}$ and $\theta_{\mathrm{X}}$ are the fraction of active sites occupied by intermediate species $i$ and unoccupied active sites, respectively. The variables on the left hand side of the above expressions can be modified by replacing $\theta_{\mathrm{CH}_{2}}=$ $\theta_{\mathrm{H}_{2}}$ and $\theta_{\mathrm{OH}}=\theta_{\mathrm{H}}$ since these species are formed due to the dissociation of methane and steam, respectively. Therefore,

$\theta_{\mathrm{CH}_{2}}=\theta_{X} \sqrt{K_{\mathrm{CH}_{4}} P_{\mathrm{CH}_{4}}}$

$\theta_{\mathrm{H}}=\theta_{X} \sqrt{K_{\mathrm{H}_{2} \mathrm{O}} P_{\mathrm{H}_{2} \mathrm{O}}}$

and the site balance for $\mathrm{X}$ suggests

$1=\theta_{X}+\theta_{\mathrm{CH}_{2}}+\theta_{H}+\sum_{i \neq \mathrm{CH}_{2}} \theta_{i}$

hence, if $\theta_{\mathrm{CH}_{2}}$ and $\theta_{\mathrm{H}}$ are most abundant reactive intermediates, the site balance is reduced to

$1=\theta_{X}+\theta_{\mathrm{CH}_{2}}+\theta_{\mathrm{H}}$, since $\sum_{i \neq \mathrm{CH}_{2}} \theta_{i} \approx 0 ;$ substituting $\theta_{\mathrm{CH}_{2}}$ and $\theta_{\mathrm{H}}$ in the above site balance, we get $1=\theta_{X}+\theta_{X} \sqrt{K_{\mathrm{CH}_{4}} P_{\mathrm{CH}_{4}}}+\theta_{X} \sqrt{K_{\mathrm{H}_{2} \mathrm{O}} P_{\mathrm{H}_{2} \mathrm{O}}}$,

$\theta_{X}=\frac{1}{1+\sqrt{K_{\mathrm{CH}_{4}} P_{\mathrm{CH}_{4}}+\sqrt{K_{\mathrm{H}_{2} \mathrm{O}} P_{\mathrm{H}_{2} \mathrm{O}}}}}$.

Assuming the surface reaction of most abundant reactive intermediates as the rate-determining step,

$r=k \theta_{\mathrm{CH}_{2}} \theta_{\mathrm{OH}}$,

$r=k\left(\theta_{X} \sqrt{K_{\mathrm{CH}_{4}} P_{\mathrm{CH}_{4}}}\right)\left(\theta_{X} \sqrt{K_{\mathrm{H}_{2} \mathrm{O}} P_{\mathrm{H}_{2} \mathrm{O}}}\right)$.

$r=\frac{k_{r x n} \sqrt{P_{\mathrm{CH}_{4}} P_{\mathrm{H}_{2} \mathrm{O}}}}{\left(1+\sqrt{K_{\mathrm{CH}_{4}} P_{\mathrm{CH}_{4}}}+\sqrt{K_{\mathrm{H}_{2} \mathrm{O}} P_{\mathrm{H}_{2} \mathrm{O}}}\right)^{2}}$,

where $k_{r x n}=\sqrt{K_{\mathrm{CH}_{4}} K_{\mathrm{H}_{2} \mathrm{O}}}$.

2. Eley-Rideal model for associative molecular adsorption of $\mathrm{CH}_{4}$ with $\mathrm{H}_{2} \mathrm{O}$ in gas phase. Since methane is adsorbed associatively on the site $\mathrm{X}$ while steam is unabsorbed,

$\theta_{\mathrm{CH}_{4}}=K_{\mathrm{CH}_{4}} P_{\mathrm{CH}_{4}} \theta_{X}$

site balance for $\mathrm{X}$ suggests

$1=\theta_{X}+\theta_{\mathrm{CH}_{4}}$,

$1=\theta_{X}+K_{\mathrm{CH}_{4}} P_{\mathrm{CH}_{4}} \theta_{X}$,

$\theta_{X}=\frac{1}{1+K_{\mathrm{CH}_{4}} P_{\mathrm{CH}_{4}}}$.

Assuming the bimolecular reaction between methane which is adsorbed on the surface and unabsorbed steam in gas phase as the rate-determining step,

$r=k \theta_{\mathrm{CH}_{4}}+P_{\mathrm{H}_{2} \mathrm{O}}$,

$r=k\left(K_{\mathrm{CH}_{4}}+P_{\mathrm{CH}_{4}} \theta_{X}\right) P_{\mathrm{H}_{2} \mathrm{o}}$,

$r=\frac{k_{\mathrm{rxn}} P_{\mathrm{CH}_{4}} P_{\mathrm{H}_{2} \mathrm{o}}}{1+K_{\mathrm{CH}_{4}}+P_{\mathrm{CH}_{4}}}$,

where $k_{r x n}=k K_{C_{4}}$.

\section{References}

1. Simpson AP, Lutz AE (2007) Exergy analysis of hydrogen production via steam methane reforming. Int $\mathrm{J}$ Hydrogen Energy 3:4811-4820

2. Jin H, Xu Y, Lin R, Han W (2008) A proposal for a novel multifunctional energy system for the production of hydrogen and power. Int J Hydrogen Energy 33:9-19

3. Fogler HS (2006) Element of chemical reaction engineering, 4th edn. Prentice Hall, New Jersey

4. Foo SY, Cheng CK, Nguyen T, Adesina AA (2011) Kinetic study of methane $\mathrm{CO}$ reforming on $\mathrm{Co}-\mathrm{Ni} / \mathrm{Al}_{2} \mathrm{O}_{3}$ and $\mathrm{Ce}-\mathrm{Co}-\mathrm{Ni} / \mathrm{Al}_{2} \mathrm{O}_{3}$ catalysts. Catal Today 164:221-226 
5. Parmar RD, Kundu A, Thurgood C, Peppley BA, Karan K (2010) Kinetic studies of the autothermal reforming of tetradecane over $\mathrm{Pt} / \mathrm{Al}_{2} \mathrm{O}_{3}$ catalyst in a fixed-bed reactor. Fuel 89:1212-1220

6. Cheng CK, Foo SY, Adesina AA (2010) Glycerol steam reforming over bimetallic $\mathrm{Co}-\mathrm{Ni} / \mathrm{Al}_{2} \mathrm{O}_{3}$. Ind Eng Chem Res 49:10804-10817

7. Halabi MH, de Croon MHJM, van der Schaaf J, Cobden PD, Schouten JC (2010) Low temperature catalytic methane steam reforming over ceria-zirconia supported rhodium . Appl Catal A 389:80-91

8. Peela NR, Kunzru D (2011) Steam reforming of ethanol in a microchannel reactor: kinetic study and reactor simulation. Ind Eng Chem Res 50:12881-12894

9. Gawade PV, Patel D, Lipscomb GG, Abraham MA (2010) Kinetics and modeling of the flexible fuel reformer: n-hexadecane steam reforming and combustion. Ind Eng Chem Res 49:6931-6940

10. Urchaga P, Baranton S, Coutanceau C, Jerkiewicz G (2012) Evidence of an Eley-Rideal mechanism in the stripping of a saturation layer of chemisorbed $\mathrm{CO}$ on platinum nanoparticles. Langmuir 28:13094-13104

11. Gokon N, Yamawaki Y, Nakazawa D, Kodama T (2011) Ni/ $\mathrm{MgO}-\mathrm{Al}_{2} \mathrm{O}_{3}$ and Ni-Mg-O catalyzed $\mathrm{SiC}$ foam absorbers for high temperature solar reforming of methane. Int J Hydrogen Energy $36: 203-215$

12. Xu J, Froment GF (1989) Methane steam reforming, methanation and water-gas shift I. Intrinsic kinetics. AIChE J 35:88-96

13. Wanga Y, Yoshibaa F, Kawasea M, Watanabea T (2009) Performance and effective kinetic models of methane steam reforming over Ni/YSZ anode of planar SOFC. Int J Hydrogen Energy 34:3885-3893

14. Bradford MCJ, Vannice MA (1996) Catalytic reforming of methane with carbon dioxide over nickel catalyst, II Reaction kinetics. Appl Catal A 142:97-122

15. Berman A, Karn RK, Epstein M (2005) Kinetics of steam reforming of methane on $\mathrm{Ru} / \mathrm{Al}_{2} \mathrm{O}_{3}$ catalyst promoted with $\mathrm{Mn}$ oxides. Appl Catal A 282:73-83

16. Dicks AL, Pointon KD, Siddle A (2000) Intrinsic reaction kinetics of methane steam reforming on a nickel/zirconia anode. J Power Sources 86:523-530

17. Wei J, Iglesia E (2004) Isotopic and kinetic assessment of the mechanism of reactions of $\mathrm{CH}_{4}$ with $\mathrm{CO}_{2}$ or $\mathrm{H}_{2} \mathrm{O}$ to form synthesis gas and carbon on nickel catalysts. J Catal 224:370-383

18. Zeppieri M, Villa PL, Verdone N, Scarsella M, De Filippis P (2010) Kinetic of methane steam reforming reaction over nickeland rhodium-based catalysts. Appl Catal A 387:147-154

19. Rostrup-Nielsen JR, Sehested J, Norskov JK (2002) Hydrogen and synthesis gas by steam- and $\mathrm{CO}_{2}$ reforming. Adv Catal 47:65-139

20. Isha R, Williams PT (2012) Experimental design methodology for optimizing catalytic performance of $\mathrm{Ni} / \mathrm{Ce} / \alpha-\mathrm{Al}_{2} \mathrm{O}_{3}$ catalyst for methane steam reforming. J Energy Inst 85:22-28

21. Arcotumapathy V, Vo DN, Chesterfield D, Tin CT, Siahvashi A, Lucien FP, Adesina AA (2014) Catalyst design for methane steam reforming. Appl Catal A 479:87-102
22. Arcotumapathy V, Siahvashi A, Adesina AA (2012) A new weighted optimal combination of ANNs for catalyst design and reactor operation: methane steam reforming studies. AIChE J 58:2412-2427

23. Maestri M, Vlachos DG, Beretta A, Forzatti P, Groppi G, Tronconi E (2009) Dominant reaction pathways in the catalytic partial oxidation of $\mathrm{CH}_{4}$ on $\mathrm{Rh}$. Top Catal 52:1983-1988

24. Dumesic JA, Huber GW, Boudart M (2008) Principles of heterogeneous catalysis. In: Ertl G, Knözinger H, Schüth FJ, Weitkamp (eds) Handbook of heterogeneous catalysis, 2nd edn. Wiley-VCH, Weinheim, p 1-15

25. Nwalor JU, Goodwin JG Jr, Biloen P (1989) Steady-state isotopic transient-kinetic analysis of iron-catalyzed ammonia synthesis. J Catal 117:121-134

26. Zhao D, Feng J, Huo Q, Melosh N, Fredrickson GH, Chmelka BF, Stucky GD (1998) Triblock copolymer syntheses of mesoporous silica with periodic 50 to 300 angstrom pores. Science 279:548-552

27. Yuranov I, Moeckli P, Suvorova E, Buffat P, Kiwi-Minsker L, Renken A (2003) $\mathrm{Pd} / \mathrm{SiO}_{2}$ catalysts: synthesis of pd nanoparticles with controlled size in mesoporous silica. J Mol Catal A 192:239-251

28. Srivastava R, Srinivas D, Ratnasamy P (2006) Sites for $\mathrm{CO}_{2}$ activation over amine-functionalized mesoporous Ti(Al)-SBA-15 catalysts. Microporous Mesoporous Mat 90:314-326

29. Liu W, Lai SY, Dai H, Wang S, Sun H, Au CT (2007) Oxidative dehydrogenation of $n$-butane over mesoporous $\mathrm{VO}_{\mathrm{x}} / \mathrm{SBA}-15$ catalysts. Catal Lett 113:147-154

30. Jakobsen JG, Jørgensen TL, Chorkendorff I, Sehested J (2010) Steam and $\mathrm{CO}_{2}$ reforming of methane over a $\mathrm{Ru} / \mathrm{ZrO}_{2}$ catalyst. Appl Catal A 377:158-166

31. Vannice MA (2005) Kinetics of catalytic reactions. Springer, New York

32. Laosiripojana N, Assabumrungrat S (2005) Methane steam reforming over $\mathrm{Ni} / \mathrm{Ce}-\mathrm{ZrO}_{2}$ catalyst: influences of $\mathrm{Ce}-\mathrm{ZrO}_{2}$ support on reactivity, resistance toward carbon formation, and intrinsic reaction kinetics. Appl Catal A 290:200-211

33. Jones G, Jakobsen JG, Shim SS, Kleis J, Andersson MP, Rossmeisl J, Abild-Pedersen F, Bligaard T, Helveg S, Hinnemann B, Rostrup-Nielsen JR, Chorkendorff I, Sehested J, Nørskov JK (2008) First principles calculations and experimental insight into methane steam reforming over transition metal catalysts. J Catal 259:147-160

34. Agnelli ME, Ponzi EN, Yeramian AA (1987) Catalytic deactivation on methane steam reforming catalysts. 2. kinetic study. Ind Eng Chem Res 26:1707-1713

35. Ahmed K, Foger K (2000) Kinetics of internal steam reforming of methane on Ni/YSZ-based anodes for solid oxide fuel cells. Catal Today 63:479-487

36. Ross JRH, Steel MCF (1973) Mechanism of the steam reforming of methane over a co-precipitated nickel-alumina catalyst. J Chem Soc Faraday Trans 69:10-21

37. Hou K, Hughes R (2001) The kinetics of methane steam reforming over a $\mathrm{Ni} / \alpha-\mathrm{Al}_{2} \mathrm{O}_{3}$ catalyst. Chem Eng J 82:311-328 